“KOSAเn“ JIK. Vol. 7 No. 1 Mei 2019

\title{
HUBUNGAN FAKTOR PENGETAHUAN, MOTIVASI DAN TINGKAT PENDIDIKAN DENGAN KEPATUHAN PEMBERIAN IMUNISASI BCG
}

\author{
Budi Kristanto', Ernis Oki Puspita Sari
}

\begin{abstract}
Background: The Indonesian Ministry of Health (2016: 01) states that in Indonesia it is estimated that 1 million new TB cases (647 per 100,000 population) with 100,000 deaths (41 per 100,000 population). Data from the Central Java Provincial Health Office (2018), said that there were 103,840 TB cases estimated, only $44.33 \%$ (48,751 sufferers) reported, so that there were still 55,089 undiscovered patients. The results of the study prove that one effective prevention for tuberculosis is BCG immunization.

Research purposes: This study aims to determine the relationship of factors of knowledge, motivation and education level with adherence to BCG immunization.

Subject: All mothers who have children over 1 year old at Posyandu Karang Gading Village Tanon Subdistrict are 35 people.

Method: This study uses observational analytic methods with a research design correlation with a cross sectional approach to determine the relationship of knowledge, motivation and education level with adherence to implementing BCG immunization. Data obtained by questionnaire, then tabulated and analyzed using SPSS 18 for Windows.

Research result: The results of the analysis with SPSS 18 for Windows used Chi Square for the dependent variable level of knowledge $p$ value: 0.655 , motivation $p$ value: 0.109 , education level $p$ value: 0.212 .

Conclusion: there is no relationship between the level of knowledge, motivation and level of education towards the compliance of mothers taking BCG immunization actions on their children.
\end{abstract}

Keywords: knowledge, motivation, education level, compliance with BCG immunization

\section{PENDAHULUAN}

Menurut Kemenkes RI (2016: 01), di Negara Indonesia diperkirakan 1 juta kasus TB (Tuberkulosis) baru (647 per 100.000 penduduk) dengan 100.000 kematian (41 per 100.000 penduduk). Akan tetapi berdasarkan data rutin program penanggulangan TB tahun 2015, angka penemuan kasus (CNR) yang ternotifikasi adalah 330.812 kasus TB baru, 28.418 diantaranya kasus TB anak atau 9\% dari semua kasus TB. Proporsi kasus TB anak diantara semua kasus TB di Indonesia pada tahun 2010 adalah 9,4\%, kemudian menjadi $8,5 \%$ pada tahun 2011, $8,2 \%$ pada tahun $2012,7,9 \%$ pada tahun 2013 , dan $7,16 \%$ pada tahun 2014, serta 9\% pada tahun 2015. Proporsi tersebut bervariasi antar provinsi dari $0,12 \%$ sampai $50 \%$.
Variasi proporsi ini mungkin menunjukkan endemisitas yang berbeda antar provinsi, tetapi bisa juga karena perbedaan kualitas diagnosa TB anak.

Sesuai data WHO, Global Tuberculosis Report 2016, Indonesia menempati posisi kedua dengan beban TBC tertinggi di dunia. Tren insiden kasus TBC di Indonesia tidak pernah menurun, masih banyak kasus yang belum terjangkau dan terdeteksi, kalaupun terdeteksi dan telah diobati tetapi belum dilaporkan. Berdasarkan studi Global Burden of Disease, TBC menjadi penyebab kematian ke dua di dunia. Angka TBC di Indonesia berdasarkan mikroskopik sebanyak 759 per100 ribu penduduk untuk usia 15 tahun ke atas dengan 
jumlah laki-laki lebih tinggi daripada perempuan, dan jumlah di perkotaan lebih tinggi daripada di pedesaan (Kemenkes RI, 2018).

Data dari Dinas Kesehatan Provinsi Jawa Tengah (2018), estimasi kasus TBC sebanyak 103.840 penderita, yang terlaporkan baru $44.33 \%$ (48.751 penderita), sehingga masih ada 55.089 pasien yang belum ditemukan. Menurut Kholifah dan Indreswari (2015: 172), berdasarkan data profil kesehatan Provinsi Jawa Tengah, TB paru anak penting karena penyakit TB paru penyebab kematian nomor satu diantara penyakit infeksi dan menduduki tempat ketiga sebagai penyebab kematian pada semua umur setelah penyakit kardiovaskuler dan penyakit infeksi saluran napas akut. Beberapa faktor resiko yang berkaitan dengan terjadinya TB paru anak yaitu jenis kelamin, status gizi, bayi BBLR, pengetahuan ibu tentang TBC, dan imunisasi BCG.

Vaksin BCG (Bacilli CalmetteGuérin) adalah vaksin hidup yang dilemahkan yang berasal dari Mycobacterium bovis. Pemberian vaksin BCG berdasarkan Program Pengembangan Imunisasi diberikan pada bayi $0-2$ bulan. Pemberian vaksin $B C G$ pada bayi $>2$ bulan harus didahului dengan uji tuberkulin. Petunjuk pemberian vaksinasi BCG mengacu pada Pedoman Program Pemberian Imunisasi Kemenkes. Secara umum perlindungan vaksin BCG efektif untuk mencegah terjadinya TB berat seperti TB Milier dan TB Meningitis yang sering didapatkan pada usia muda. Vaksinasi BCG ulang tidak direkomendasikan karena tidak terbukti memberikan perlindungan tambahan (Kemenkes RI, 2016 : 70).

Hasil penelitian membuktikan bahwa salah satu pencegahan yang efektif untuk Tuberkulosis (TB) adalah dengan pemberian imunisasi BCG. Penelitian Wahyuny dan Fadila (2014 : 194-198), tentang gambaran pengetahuan ibu tentang pemberian imunisasi BCG di Desa Pendalian IV Koto Wilayah Kerja Puskesmas Pendalian IV Koto tahun 2013 didapat hasil tingkat pengetahuan ibu tentang imunisasi BCG mayoritas berpengetahuan kurang sebesar 50,9\%. Sedangkan penelitian Hayati, Marianthi dan Nurleli (2009 : 75-82), membahas tentang faktor-faktor yang berhubungan dengan cakupan imunisasi dasar pada bayi di Desa Kajhu Kecamatan Baitussalam Aceh Besar tahun 2009 diperoleh hasil bahwa terdapat hubungan cakupan imunisasi dengan motivasi ibu ( $p$ value $=0,003)$, dan dukungan keluarga ( $p$ value $=0,000$ ), namun tidak terdapat hubungan dengan pendidikan ibu ( $p$ value $=0,115)$, dan konseling ( $p$ value $=0,402)$. Demikian pula penelitian Dwiastuti dan Prayitno (2013 : 36-39), dengan judul faktor-faktor yang berhubungan dengan pemberian imunisasi BCG di Wilayah Puskesmas UPT Cimanggis Kota Depok Tahun 2012, mendapatkan kesimpulan bahwa adanya hubungan antara pengetahuan ibu dengan pemberian imunisasi BCG ( $p$ value $=0,000$ ), adanya hubungan antara sikap ibu dengan pemberian imunisasi BCG (p:0,003), adanya hubungan antara pendidikan ibu dengan pemberian imunisasi BCG (p:0,026), ada hubungan antara jarak tempat tinggal responden dengan pemberian imunisasi BCG ( $p$ :0,001), ada hubungan antara dukungan suami/keluarga dengan pemberian imunisasi BCG nilai $p$ sebesar 0,000, dan ada hubungan antara dukungan petugas dengan pemberian imunisasi BCG (p:0,000). Penelitian ini adalah replikasi dari penelitian-penelitian sebelumnya akan tetapi kelebihan penelitian ini 
fokus variabel bebas yang diteliti berbeda, yaitu : faktor pengetahuan, motivasi dan pendidikan orang tua. Variabel ini belum diteliti secara bersama-sama pada penelitianpenelitian terdahulu sepertidiuraikan di atas. Berdasarkan alasan tersebut maka peneliti tertarik untuk melakukan penelitian tentang "Faktor-faktor yang Mempengaruhi Pemberian Imunisasi BCG di Posyandu Desa Karang Gading Kecamatan Tanon".

\section{TUJUAN PENELITIAN}

Penelitian ini secara umum bertujuan untuk mengetahui faktorfaktor yang mempengaruhi pemberian imunisasi BCG di Posyandu Desa Karang Gading Kecamatan Tanon serta secara khusus untuk mengidentifikasi hubungan faktor tingkat pendidikan, pengetahuan dan motivasi dengan kepatuhan imunisasi BCG.

\section{METODE PENELITIAN}

Penelitian ini merupakan penelitian korelasi dengan pendekatan cross sectional untuk mengetahui hubungan tingkat pendidikan, pengetahuan dan motivasi dengan kepatuhan ibu melakukan imunisasi BCG pada anaknya di Posyandu Desa Karang Gading Kecamatan Tanon.

\section{POPULASI, SAMPEL DAN TEKNIK} SAMPLING

Populasi penelitian adalah ibu yang memiliki anak balita. Dalam penelitian ini peneliti menggunakan teknik sampling jenuh dengan responden penelitian sejumlah 35 orang.

\section{HASIL PENELITIAN}

Berdasarkan penelitian yang telah dilakukan didapatkan karakteristik responden berdasarkan umur dan pendidikan beserta hasil penelitian mengenai hubungan tingkat pendidikan, pengetahuan dan motivasi, yaitu sebagai berikut :

Tabel 1. Karakteristik Responden

\begin{tabular}{ccc}
\hline Karakteristik & $\mathrm{n}$ & $\%$ \\
\hline Usia lbu (tahun) & & \\
$20-30$ & 24 & 68.6 \\
$31-40$ & 11 & 31.4 \\
Pendidikan & & \\
SD & 10 & 28.6 \\
SMP & 21 & 60 \\
SMA/SMK & 4 & 11.44 \\
PT & 0 & 0 \\
Usia Anak & & \\
(bulan) & & \\
1 sd 12 & 5 & 14.3 \\
13 sd 24 & 9 & 25.7 \\
$>24$ bulan & 21 & 60 \\
Jumlah Anak & & \\
1 & 14 & 40 \\
2 & 16 & 45.7 \\
3 & 1 & 2.9 \\
4 & 4 & 11.4 \\
\hline
\end{tabular}

Dari tabel di atas dapat diperoleh informasi bahwa mayoritas usia responden $(68.6 \%)$ pada rentang usia 20-30 tahun. Sedangkan berdasarkan tingkat pendidikan mayoritas responden (60\%) adalah SMP. Mayoritas responden dengan anak balita dengan usia lebih dari 24 bulan $(60 \%)$ dan mayoritas dengan jumlah anak 2 orang (45.7\%).

Tabel 2.

Distribusi Frekuensi Kategori Variabel

\begin{tabular}{ccc}
\hline Variabel & $\mathrm{f}$ & $\%$ \\
\hline Tk. Pengetahuan & & \\
Baik & 33 & 94.3 \\
Buruk & 2 & 5.7 \\
Motivasi & & \\
Tinggi & 32 & 91.4 \\
Rendah & 3 & 8.6 \\
Tk. Pendidikan & & \\
$\quad$ Dasar & 31 & 88.6 \\
Menengah & 4 & 11.4 \\
\hline Jumlah & 35 & 100 \\
\hline
\end{tabular}


Tabel 2 diketahui mayoritas responden memiliki pengetahuan tentang imunisasi BCG dalam kategori baik sebesar 94.3\%, sedangkan yang berpengetahuan kurang sebesar 5.7\%. Mayoritas responden dengan motivasi kategori tinggi yaitu $91.4 \%$ sedangkan $8.6 \%$ dengan motivasi rendah. Mayoritas responden dengan tingkat pendidikan dasar (SD dan SMP) sebesar $91.4 \%$ sedangkan $11.4 \%$ dengan pendidikan menengah.

Tabel 3

Tabulasi Silang

Tingkat Pengetahuan, Motivasi, Tingkat Pendidikan dengan Kepatuhan Pemberian Imunisasi BCG

\begin{tabular}{|c|c|c|c|}
\hline \multirow{2}{*}{$\begin{array}{l}\text { Kategori } \\
\text { Depresi }\end{array}$} & \multicolumn{2}{|c|}{$\begin{array}{c}\text { Kepatuhan } \\
\text { Imunisasi BCG }\end{array}$} & \multirow{2}{*}{$P$} \\
\hline & Patuh & $\begin{array}{l}\text { Tidak } \\
\text { Patuh }\end{array}$ & \\
\hline \multirow{2}{*}{\multicolumn{4}{|c|}{$\begin{array}{c}\text { Tingkat } \\
\text { Pengetahuan }\end{array}$}} \\
\hline & & & \\
\hline Baik & 30 & 3 & \\
\hline Buruk & 2 & 0 & 0.655 \\
\hline \multicolumn{4}{|l|}{ Motivasi } \\
\hline Tinggi & 30 & 2 & \\
\hline $\begin{array}{l}\text { Rendah } \\
\text { Tingkat }\end{array}$ & 2 & 1 & 0.109 \\
\hline Pendidikan & & & \\
\hline Dasar & 29 & 2 & \\
\hline $\begin{array}{l}\text { Menengah- } \\
\text { tinggi }\end{array}$ & 3 & 1 & 0.212 \\
\hline
\end{tabular}

Dari tabulasi silang antara tingkat pengetahuan dengan kepatuhan imunisasi BCG diperoleh hasil bahwa terdapat responden dengan tingkat pengetahuan baik sebanyak $33(94.3 \%)$, yang masuk kategori patuh sebanyak $30(91 \%)$ dan tidak patuh sebanyak $3(9 \%)$. Sedangkan responden dengan tingkat pengetahuan buruk sebanyak 2 $(5.7 \%)$ dan seluruhnya masuk dalam kategori patuh.

Untuk tabulasi silang antara motivasi dengan kepatuhan imunisasi BCG diperoleh informasi 32 responden dengan motivasi tinggi terdapat 30 orang $(94 \%)$ patuh dan sisanya yaitu 2 orang (6\%) tidak patuh, sedangkan 3 responden dengan motivasi rendah terdapat 2 orang $(66.7 \%)$ patuh dan 1 orang (33.3\%) tidak patuh.

Untuk tabulasi silang antara tingkat pendidikan dengan kepatuhan imunisasi BCG diperoleh informasi 31 responden dengan pendidikan dasar terdapat 29 orang $(93.5 \%)$ patuh dan 2 orang (6.5\%) tidak patuh. Sedangkan dari 4 responden dengan pendidikan menengah diperoleh 3 orag (75\%) patuh dan 1 orang $(25 \%)$ tidak patuh.

\section{PEMBAHASAN}

Pada penelitian ini diperoleh informasi yaitu ibu dari anak balita, berdasarkan usianya yaitu $68.6 \%$ dalam rentang usia 20-30 tahun sedangkan $31.4 \%$ dalam rentang usia 31-40 tahun. Mayoritas responden dalam usia produktif yang banyak aktivitas atau bekerja yaitu $68.6 \%$, akan tetapi status bekerja tidak ada hubungan dengan kepatuhan seorang ibu untuk mengimunisasikan anaknya. Hal tersebut sesuai dengan hasil penelitian Nugraheni, Mufdlillah dan Isnaeni (2009), yang menyebutkan bahwa bahwa tidak ada perbedaan antara ibu bekerja dan tidak bekerja untuk mengimunisasikan anaknya $(p=0.414)$. Hasil penelitian ini menunjukkan mayoritas responden dengan jumlah anak 2 orang (45.7\%), dan secara keseluruhan responden $60 \%$ diantaranya memiliki anak 2 atau lebih. Dengan jumlah mayoritas memiliki anak lebih dari 1 memberikan informasi bahwa mereka bukan orang tua baru, setidaknya memiliki pengalaman melakukan imunisasi untuk anak yang sebelumnya.

Pengalaman diartikan sebagai sesuatu yang pernah dialami, baik dijalani, dirasai maupun ditanggung (KBBI, 2005). Pengalaman dapat 
diartikan juga sebagai memori episodik, yaitu memori yang menerima dan menyimpan peristiwa yang terjadi atau dialami individu pada waktu dan tempat tertentu, yang berfungsi sebagai referensi otobiografi (Syah, 2008). Pengalaman merupakan hal yang tidak dapat dipisahkan dari kehidupan manusia sehari harinya. Pengalaman juga sangat berharga bagi setiap manusia dan pengalaman juga dapat diberikan kepada siapa saja untuk digunakan dan menjadi pedoman serta pembelajaran manusia. Dalam kaitannya dengan kepatuhan ibu dalam melakukan imunisasi BCG pada anaknya, ibu yang memiliki anak yang ke-2 dan selanjutnya, maka sudah memiliki pengalaman dan bekal informasi dari anaknya yang terdahulu.

Untuk variabel pengetahuan, pada penelitian ini diperoleh hasil dari 35 responden yang diteliti, 33 responden (94.3\%), memiliki pengetahuan yang baik, hanya 2 responden (5.7\%) dengan pengetahuan yang buruk. Menurut Notoatmodjo (2010), pengetahuan sangat penting sebagai pendorong dalam mengambil keputusan dan melakukan tindakan. Hal ini sesuai dengan teori pendorong yang menyebutkan bahwa daya pendorong adalah semacam naluri tetap hanya satu dorongan kekuatan yang luas terhadap satu arah yang umum. Dalam hal ini adalah pendorong seorang ibu untuk mengimunisasikan bayinya.

Setelah dilakukan analisa dan tabulasi silang antara pengetahuan ibu dengan kepatuhan melakukan imunisasi pada anaknya diperoleh hasil bahwa terdapat responden dengan tingkat pengetahuan baik sebanyak $33(94.3 \%)$, yang masuk kategori patuh sebanyak $30(91 \%)$ dan tidak patuh sebanyak 3 (9\%). Sedangkan responden dengan tingkat pengetahuan buruk sebanyak $2(5.7 \%)$ dan seluruhnya masuk dalam kategori patuh.

Dari responden sejumlah 33 orang dengan tingkat pengetahuan baik, ternyata sebanyak 30 (91\%) patuh dan sebanyak 3 (9\%) tidak patuh. Hal ini menunjukkan bahwa tidak semua ibu yang tahu tentang imunisasi patuh untuk mengimunisasikan anaknya tepat sesuai dengan waktu atau jadwal yang sudah ditentukan. Selain pengetahuan ada variabel yang lain yang mempengaruhi ibu mengimunisasikan anaknya diantaranya adalah dukungan keluarga. Seperti dikemukakan oleh Ritonga, Syarifah dan Tukiman (2014) yang menyebutkan bahwa terdapat hubungan yang bermakna antara dukungan keluarga dengan kepatuhan ibu melaksanakan imunisasi dasar. Akan tetapi faktor dukungan keluarga tidak menjadi variabel dalam penelitian ini.

Sedangkan sebaliknya responden dengan tingkat pengetahuan buruk sebanyak 2 orang (5.7\%) seluruhnya masuk dalam kategori patuh. Hal ini menunjukkan tidak semua orang yang memiliki pengetahuan tentang imunisasi yang buruk selalu tidak patuh untuk mengimunisasikan anaknya. Hal ini karena banyak hal yang mempengaruhi perilaku seseorang. Salah satu hal yang mungkin terjadi adalah karena meniru orang lain di sekitarnya.

Hal tersebut sesuai dengan teori pembelajaran sosial yang dikemukakan Miller dan Dollard dalam Mustafa (2011), bahwa perilaku peniruan (imitative behavior) kita terjadi karena kita merasa telah memperoleh imbalan ketika kita meniru perilaku orang lain dan memperoleh hukuman ketika kita tidak menirunya. Agar seseorang bisa belajar mengikuti 
aturan baku yang telah ditetapkan oleh masyarakat maka para individu harus dilatih, dalam berbagai situasi, sehingga mereka merasa nyaman ketika melakukan apa yang orang lain lakukan, dan merasa tidak nyaman ketika tidak melakukannya. Hasil analisis statistik antara variabel pengetahuan dan kepatuhan ibu melakukan imunisasi BCG pada anaknya dengan Chi Square diperoleh nilai $\mathrm{p}: 0.655$ dimana nila $p>0.05$ yang berarti tidak ada hubungan antara pengetahuan dengan kepatuhan ibu melakukan imunisasi BCG pada anaknya. Hal ini dapat diartikan bahwa ibu dengan pengetahuan tinggi tidak selalu patuh atau sebaliknya ibu dengan pengetahuan rendah tidak selalu tidak patuh melakukan imunisasi BCG pada anaknya oleh karena berbagai faktor yang tidak diteliti pada penelitian ini.

Pada variabel motivasi ibu melakukan imunisasi, diperoleh informasi bahwa $91.4 \%$ responden memiliki motivasi yang tinggi dan $8.6 \%$ memiliki motivasi yang rendah. Setelah dilakukan tabulasi silang diperoleh informasi bahwa dari 32 responden yang memiliki motivasi tinggi, 30 (94\%) patuh dan sisanya 2 $(6 \%)$ tidak patuh mengimunisasikan anaknya. Sedangkan dari 3 responden yang memiliki motivasi rendah $2(66.7 \%)$ patuh dan 1 (33.3\%) tidak patuh mengimunisasikan anaknya. Dari hasil ini memberikan informasi bahwa tidak selalu orang yang memiliki motivasi yang tinggi melakukan imunisasi pada anaknya, demikian juga sebaliknya orang yang memiliki motivasi rendah belum tentu tidak melakukan tindakan imunisasi BCG pada anaknya. Hal tersebut tentu saja banyak hal yang mempengaruhinya. Donsu (2017:231), mengemukakan bahwa motivasi berasal dari kata motif yang berarti dorongan atau alasan. Motif merupakan tenaga pendorong yang mendorong manusia untuk bertindak atau suatu tenaga di dalam diri manusia, yang menyebabkan manusia bertindak atau melakukan sesuatu. Dengan kata lain, motivasi adalah sebuah proses untuk mencapai suatu tujuan. Tingkat kemauan (atau motivasi) orang berbeda-beda, karena alasan yang berkait dengan kebutuhan untuk kegiatan yang sama, dapat berbeda-beda.

Menurut Donsu (2017:233), tujuan motivasi orang satu dengan yang lainnya berbeda. Mereka menempatkan dan mendasarkan atas nilai-nilai tertentu sesuai dengan pandangan dan mendasarkan atas nilai-nilai tertentu sesuai dengn pandangan dan dasar hidupnya. Meskipun demikian secara mendasar atau hakiki, tujuan motivasi siapapun adalah untuk mendapatkan sesuatu atau terhindar dari sesuatu. Mendapatkan sesuatu tentu saja cenderung konteksnya positif, dan terhindar sesuatu cenderung konteksnya negatif seperti hukuman. Dalam konteks tindakan melakukan imunisasi BCG ini dapat dinilai bahwa mayoritas ibu dengan motivasi tinggi patuh mengimunisasikan anaknya yaitu 30 $(94 \%)$ patuh dan sisanya $2(6 \%)$ tidak patuh mengimunisasikan anaknya. Sedangkan dari 3 responden yang memiliki motivasi rendah $2(66.7 \%)$ patuh dan 1 (33.3\%) tidak patuh mengimunisasikan anaknya. Hal ini menunjukkan bahwa motivasi seseorang bukan satu-satunya faktor yang mendorong seorang ibu mengimunisasikan BCG pada anaknya.

Hal tersebut dapat dijelaskan seperti dikemukakan Nursalam (2015:106107), motivasi mempunyai tiga unsur utama yaitu kebutuhan, dorongan, dan tujuan. Kebutuhan 
terjadi bila individu merasa ada ketidakseimbangan antara apa yang mereka miliki dengan apa yang mereka harapkan. Dorongan merupakan kekuatan mental yang berorientasi pada pemenuhan harapan atau pencapaian tujuan. Dorongan yang berorientasi pada tujuan tersebut merupakan inti dari motivasi.

Menurut Nursalam (2015:107), motivasi dibedakan menjadi 2 yaitu motivasi internal dan eksternal. Motivasi internal merupakan motivasi yang berasal dari dalam diri seseorang. Keperluan dan keinginan yang ada dalam diri seseorang akan menimbulkan motivasi internalnya. Kekuatan ini akan mempengaruhi pikirannya yang selanjutnya akan mengarahkan perilaku orang tersebut. Sedangkan motivasi eksternal tidak dapat dilepaskan dari motivasi internal. Motivasi eksternal adalah motivasi yang timbul dari luar/lingkungan. Misalnya: motivasi eksternal dalam belajar antara lain berupa penghargaan, pujian, hukuman atau celaan yang diberikan oleh orang lain.

Dalam hal ini seorang ibu yang memiliki motivasi yang tinggi untuk melakukan imunisasi BCG pada anaknya, tetapi lingkungan tidak mendukung, sehingga menundanya. Sebaliknya ibu yang memiliki motivasi yang rendah tetapi dorongan eksternal begitu kuat sehingga melakukan tindakan imunisasi BCG pada anaknya. Akan tetapi pada penelitian ini peneliti tidak melakukan penelitian tentang motivasi internal dan eksternal tersebut, sehingga alasan ini masih berupa hipotesa.

Beberapa hal yang mempengaruhi seorang ibu tidak mengimunisasikan anaknya adalah bahwa di samping informasi tentang manfaat dan kebaikan imunisasi, disisi yang lain banyak pula informasi lain diantaranya seperti diungkapkan oleh Cahyono (2010:40), bahwa pemberian begitu banyak vaksin akan menyebabkan membanjirnya sistem imun. Banyak orang tua menjadi ragu dengan begitu banyaknya jenis vaksin yang harus diberikan kepada anaknya. Informasi yang lain mempersepsikan bahwa sepanjang anak-anak lain sudah mendapatkan vaksin, anak tersebut tidak perlu vaksinasi. Karena semua anak telah mendapatkan vaksinasi, kondisi demikian akan menjadi pagar perlindungan bagi sebagian kecil anak yang belum mendapat vaksinasi. Selain itu, penyakit menular sudah menurun dan pemberian vaksin dengan memasukkan virus ke dalam tubuh bisa membuat anak sakit, serta informasi bahwa vaksin menyebabkan autisme pada anak. Walaupun sudah banyak penelitian yaitu berdasarkan evaluasi dari 14 penelitian, disimpulkan bahwa anakanak yang mendapatkan vaksin MMR dan yang tidak mendapatkan vaksin MMR resiko mendapatkan autisme sama saja, artinya vaksin tidak memicu terjadinya autisme. Walaupun demikian informasi yang diterima tiap orang memberikan respon yang berbeda.

Hal tersebut dibuktikan pada penelitian ini yang diperoleh dari hasil uji statistik dengan Chi Square antara variabel motivasi dengan kepatuhan imunisasi BCG didapatkan nila $p$ : 0.109 yang berarti bahwa nilai $p>0.05$ sehingga dapat disimpulkan bahwa tidak ada hubungan antara motivasi dengan kepatuhan ibu melakukan tindakan imunisasi pada anaknya.

Pada variabel tingkat pendidikan diperoleh informasi bahwa terdapat 31 responden (88.6\%) dengan tingkat pendidikan dasar dan 4 responden (11.4\%) dengan pendidikan menengah sampai 
dengan tinggi. Hasil tabulasi silang dengan variabel kepatuhan ibu melakukan imunisasi BCG pada anaknya diperoleh untuk responden dengan pendidikan dasar $93.5 \%$ patuh sedangkan $6.5 \%$ tidak patuh sedangkan respnden dengan tingkat pendidikan menengah-tinggi $75 \%$ patuh dan $25 \%$ tidak patuh.

Dari uraian tersebut dapat diperoleh informasi $75 \%$ responden dengan tingkat pendidikan menengah-tinggi patuh melakukan imunisasi pada anaknya. Hal tersebut sesuai dengan paparan Notoatmodjo (2007), yang menyebutkan bahwa ada pengaruh tingkat pendidikan terhadap penggunaan fasilitas pelayanan kesehatan. Paparan tersebut menjelaskan bahwa melakukan imunisasi BCG dipengaruhi oleh tingkat pendidikan dapat membuat orang menjadi berpandangan lebih luas berfikir dan bertindak secara rasional sehingga latar belakang pendidikan seseorang dapat mempengaruhi penggunaan pelayanan kesehatan.

Pada umumnya semakin tinggi pendidikan seseorang maka akan semakin baik pula tingkat pengetahuannya. lbu dengan pendidikan yang relatif tinggi cenderung memiliki kemampuan untuk menggunakan sumber daya keluarga yang lebih baik dibandingkan dengan ibu yang berpendidikan rendah, sehingga memberi dampak dalam mengakses pengetahuan khususnya di bidang kesehatan untuk penerapan dalam kehidupan keluarga terutama pada pengasuh anak balita (Notoatmodjo, 2007).

Akan tetapi pada sisi yang lain, dari penelitian ini juga diperoleh informasi bahwa responden dengan pendidikan dasar $93.5 \%$ patuh sedangkan $6.5 \%$ tidak patuh melakukan tindakan imunisasi BCG pada anaknya. Hal ini memberikan informasi bahwa pendidikan formal yang tinggi tidak selalu menjadi penentu seseorang dalam melakukan tindakan. Diperkuat dengan uji statistik hubungan antara variabel pendidikan dan kepatuhan ibu melakukan imunisasi pada anaknya diperoleh nilai $p: 0.212$, dimana $p>0.05$, sehingga dapat disimpulkan bahwa tidak ada hubungan antara tingkat pendidikan dengan kepatuhan ibu melakukan imunisasi BCG pada anaknya.

\section{KESIMPULAN}

1. Mayoritas responden memiliki pengetahuan tentang imunisasi BCG dalam kategori baik sebesar 94.3\%, dan berpengetahuan buruk sebesar $5.7 \%$.

2. Mayoritas responden dengan motivasi kategori tinggi yaitu $91.4 \%$ sedangkan $8.6 \%$ dengan motivasi rendah.

3. Mayoritas responden dengan tingkat pendidikan dasar (SD dan SMP) sebesar $88.6 \%$ sedangkan $11.4 \%$ dengan pendidikan menengah-tinggi.

4. Mayoritas responden dalam kategori patuh sebesar $91 \%$, sedangkan yang tidak patuh sebesar $9 \%$.

5. Dapat disimpulkan bahwa tidak ada hubungan antara tingkat pengetahuan $(p=0.655)$, motivasi $(p=0.109)$ dan tingkat pendidikan (0.212) terhadap kepatuhan ibu melakukan tindakan imunisasi BCG pada anaknya.

\section{SARAN}

1. Bagi masyarakat, terutama keluarga yang memiliki anak balita usia kurang dari 1 tahun sebaiknya melakukan pemberian imunisasi BCG untuk memberikan kekebalan pada kuman TBC.

2. Perawat khususnya dalam lingkup komunitas dapat lebih meningkatkan perannya terutama 
mengedukasi masyarakat terkait pentingnya imunisasi BCG untuk pencegahan TBC.

3. Bagi peneliti selanjutnya dapat melakukan penelitian faktor yang lain yang berkontribusi terhadap kepatuhan ibu dalam memberikan imunisasi BCG pada anaknya seperti motivasi internal dan eksternal dari ibu.

\section{DAFTAR PUSTAKA}

Cahyono, J.B. Suharjo B., et al. 2010. Vaksinasi Cara Ampuh Cegah Penyakit Infeksi. Kanisius, Yogyakarta.

Donsu, Jenita Doli. 2017. Psikologi Keperawatan. Pustaka Baru Press, Yogyakarta.

Dwiastuti, Putri dan Nanang Prayitno. 2013. "FaktorFaktor Yang Berhubungan Dengan Pemberian Imunisasi BCG Di Wilayah Puskesmas UPT Cimanggis Kota Depok Tahun 2012". Jurnal Ilmiah Kesehatan, Volume 5 Nomor 1. http://digilib.unisayogya. ac.id/434/1/NASKAH\%2520 PUBLIKASI.pdf\&ved=2ahuke wiuy07llsvyahuqsy8khc9ces qfjamegqibbab\&usg=aovvaw oslvotc_vggy4e6qopl6nf.

Diakses pada tanggal 18 Desember 2018.

Hasan, Alwi, et al. 2005. Kamus Besar Bahasa Indonesia. Departemen Pendidikan Nasional Balai Pustaka, Jakarta.

Hayati, Wirda, Dewi Marianthi dan Nurleli. 2009." Faktor-Faktor Yang Berhubungan dengan Cakupan Imunisasi Dasar pada Bayi di Desa Kajhu Kecamatan Baitussalam Aceh Besar Tahun 2009". Jurnal Keperawatan Volume 1, Nomor 1. http://ejournal.umm. ac.id/ index.

php/

keperawatan/article/view/391

. Diakses pada tanggal 15 September 2017.

Kemenkes RI. 2016. Petunjuk Teknis Manajemen dan Tatalaksana TB pada Anak. Kemenkes RI, Jakarta.

Kholifah, Siti Nurul dan Sri Andarini Indreswari. 2015." Faktor Terjadinya Tuberkulosis Paru pada Anak Berdasarkan Riwayat Kontak Serumah". Jurnal VISIKES Vol. 14 / No. 2 / September 2015. http://download .portal garuda.org/articel. php\% 3Farticle\%3d456083\%26val \%3d5189\%2 6title\%3 dfaktor $\% 2520$ terjadinya\%2520t berkulosis\%2520paru\%2520 padaanak\%2520

berdasarkan \%2520riwayat\%2520kon tak\%2520serum Diakses pada tanggal 15 September 2017.

Kemenkes RI. 2018. Kemenkes Percepat Atasi 3 Masalah Kesehatan.http://www.depke s.go.id/article/print/18030700 005/rakerkesnas-2018kemenkespercepat-atasi-3masalah-kesehatan.html. diskses 8 Januari 2019.

Mustafa, Hasan. 2011. Perilaku Manusia Dalam Perspektif Psikologi Sosial. Jurnal Administrasi Bisnis. Center For Bussines Studies.Fisip Unpar.

http://journal.unpar.ac.id/inde x.php/JurnalAdministrasiBisni s/article/view/410. Diakses 8 Januari 2019

Notoatmodjo, Soekidjo. 2010 Promosi Kesehatan dan Perilaku Kesehatan. Rineka Cipta, Jakarta.

Ridha, H Nabiel. 2014. Buku Ajar Keperawatan Anak. Pustaka Pelajar, Yogyakarta. 